
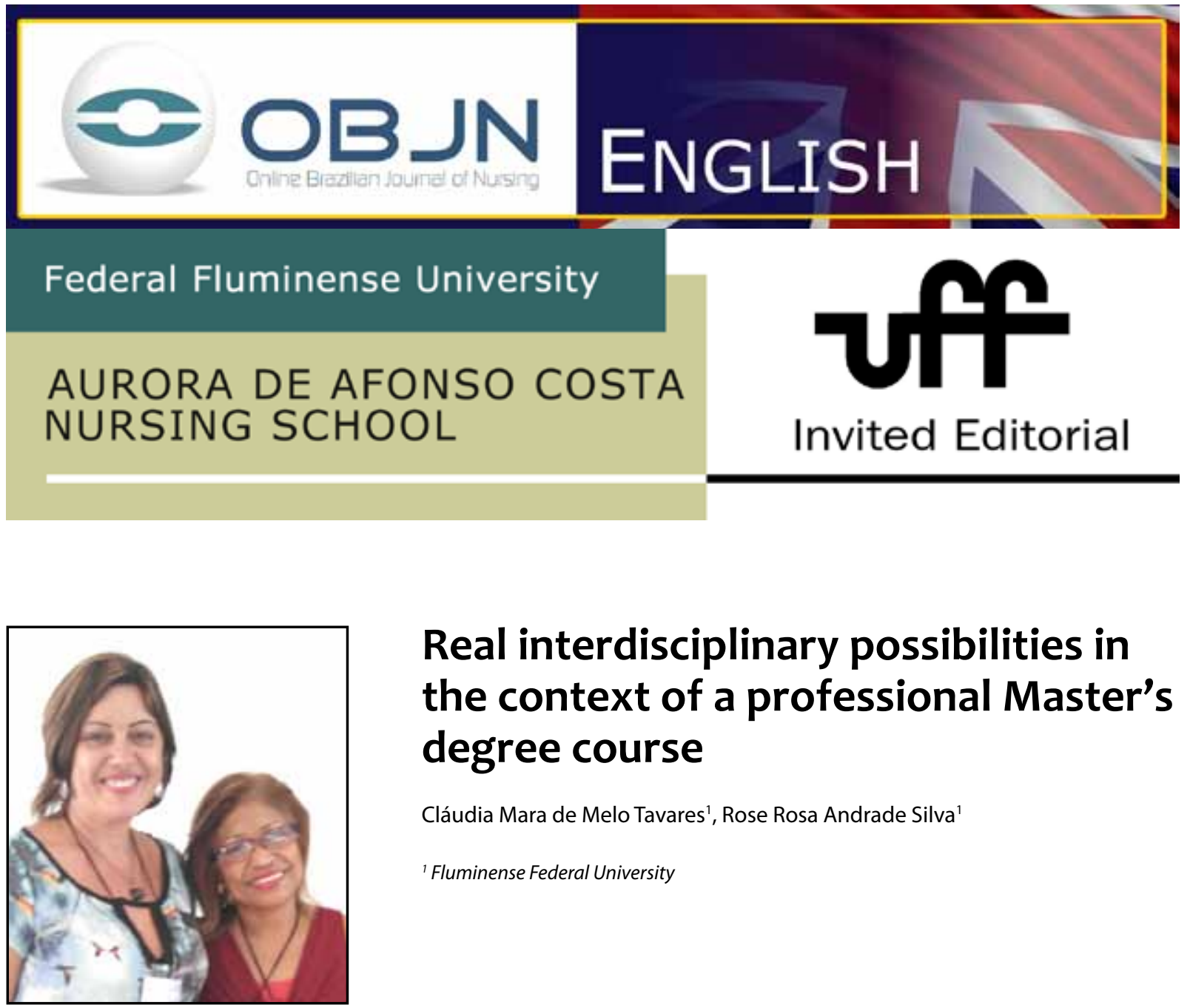

\title{
Real interdisciplinary possibilities in the context of a professional Master's degree course
}

\author{
Cláudia Mara de Melo Tavares ${ }^{1}$, Rose Rosa Andrade Silva ${ }^{1}$ \\ ${ }^{1}$ Fluminense Federal University
}

\begin{abstract}
This editorial presents a reflection on interdisciplinarity in the context of the Professional Master's Degree in Health Education, aiming to discuss the experience with interdisciplinarity in this program since 2011 to the present day, and its interface with the Public Health System. Our main point is the meaning and preponderance that interdisciplinary training has with regard to health professionals from a reflexive, dialogical, innovative and, above all, engaged professional perspective. We understand that interdisciplinarity while it deepens social relationships, also favors the expression of the uniqueness of individuals in the construction-reconstruction of knowledge and the process of expertise development.
\end{abstract}

Descriptors: Interdisciplinary Communication; Teaching; Curriculum 
The professional Master's degree is a modality for post-graduate studies in development, aimed at training professionals through the study of techniques, processes, or themes by incorporating the scientific method, enabling professionals to work in technical-scientific and innovative activities in order to keep pace with advances in the nursing profession ${ }^{(1)}$.

This type of post-graduate (stricto sensu) study advances the dynamic integration of theory and practice, as a means of enhancingthe traditional way of training - away from real scenarios and focused on scholarly knowledge. However, simple contact with real practice does not guarantee that it is reflective or that it promotes innovation in the professional field ${ }^{(2)}$. Society itself and the health services in particular need not only new knowledge, but"a new way of producing knowledge" ${ }^{\prime \prime 3)}$, engendered by a new political, scientific, pedagogic and emancipatory culture. Addressing this challenge is not an easy task for the professional Master's courses, because even the way knowledge has been established in society is utilitarian and functional, recognized less by the ability to deeply understand reality than the ability to transform it.

In this new context, academic and experiential knowledge need to become closer. This is because "...the passing from knowledge to action, by its own complexity, involves a series of social and natural phenomena that require an interdependence of disciplines, as well as the emergence of new disciplines"(4). Thus, the importance of an interdisciplinary approach in training is reaffirmed.

The Professional Master's Degree in Health Education (MPES) aims to train professionals capable of producing results related to different areas in health with a view to strengthening the Brazilian Public Health System (SUS), by deepening the theoretical and methodological foundations of the human, social and biological sciences that are the bases of this multidisciplinary field. This education is oriented toward professional field training and interdisciplinary practice in health care.

Currently, as part of the student group, we have nurses, physicians, physical therapists, physical educators, psychologists, nutritionists, social workers and others. Also the teaching staff is multidisciplinary in character, made up of teachers of nursing, medicine, dentistry, psychology, pharmacy, education, social sciences, physical education and philosophy.

Our fundamental strategy is based on the experience of collaborative teaching-learning and of working in groups in terms of the different opportunities presented by a postgraduate program - classes; the preparation, development and presentation of research/intervention/ innovation projects; guidance and internship training. We seek to develop collective competence and interdisciplinarity in the student and in the teaching groups as a knowledge- and action-building process.

Interdisciplinarity is a matter of openness, sharing and dialogue, where the differences between students and subject areas benefits all. The experience of conducting collective defenses of projects in Integrated Research Seminars in MPES allows us to experiment the value of interdisciplinarity. By adopting this strategy, we intend to show that, aside from the need for a scientific contribution, "...it is essential to achieve an analysis of the interdisciplinary'convergence' and co-participation"(4). Therefore, the conformism of procedures for submission and for the defense of projects and ideas in single-disciplinary and isolated examination boards which strengthens monothematic knowledge, can be avoided. Such an approach removes practices like those, valued and reinforced in the culture of post-graduate studies, ones that are sustained and reinforced 
by rigid institutional structures and the spirit of competitiveness.

The interdisciplinary approach is the subject of several studies developed by the MPES students $^{(5-6)}$. The studies developed seek, among other aims, to understand the experience of interdisciplinarity in health practices. They emphasize the need for this approach in the training of tutors, expanding the aspects of professional and academic practice in health. Such an approach is practiced in the planning and evaluation of compulsory and elective courses taken within the collegiate program. In everyday teaching practices, we observe the adoption of an interdisciplinary perspective on the part of a significant proportion of the teaching staff who, in terms of their teaching and learning methodology, build and mobilize content and strategies from shared knowledge for the creation of a unique disciplinary language, freeing their teaching from the inertia of the reproduction of isolated knowledge.

An important aspect to consider is that the MPES students have knowledge about the practice of interdisciplinarity, since the use of interdisciplinary teamwork is a requirement in the Public Health System and is fundamental to the development of the principle of comprehensive health. "The interdisciplinarity in health is woven into the fabric of the relationship between health services, it does not come from predetermined categories nor belong to an instrumental logic"(7).

Other studies conducted on health care areas $^{(8.9)}$ highlight the importance of interdisciplinary training to meet the complex demands of health care, demonstrating that this is a keycompetence of health care and necessary for the expression of professional commitment.

Thus, the professional profile we seek to develop is of teachers with a critical-reflective and broad view of society, qualified to promote integrated articulation between the sectors of education and health, who are capable of, from a concrete analysis of teachers' work in the health area, observing the historical development of the educational phenomenon, its limits and possibilities, from the perspective of building collective, interdisciplinary, critical and innovative educational practices, committed to the transformation of the wider reality of the context of health promotion.

We conclude that, with the MPES, we are creating real opportunities and an interdisciplinary perspective for future changes in education and health, in accordance with the challenges of the global ecology in the Twenty-First Century.

\section{REFERENCES}

1. CAPES. Portaria Normativa No 17 , de 28 de dezembro de 2009 - dispõe sobre o Mestrado Profissional no âmbito da Fundação Coordenação de Aperfeiçoamento de Pessoal de Nível Superior - CAPES. Diário Oficial da União 24829 dez 2009; p. 20/21.

2. Tavares CMM, Queiroz PP. The pedagogical training of students in professional master's degree programs. J. res.: fundam. care. online [ Internet ]. 2014 out [ Cited 2014 Out 1 ] 6 (4): 1313-1320. Available http://www.seer.unirio.br/index.php/ cuidadofundamental/article/view/3394/pdf_646

3. Santos BS. Renovar a teoria crítica e reinventar a emancipação social. São Paulo: Boitempo; 2007.

4. Fazenda ICA. Integração e Interdisciplinaridade no ensino brasileiro: efetividade ou ideologia. $6^{a}$ Ed. São Paulo: Edições Loyola; 2011.

5. Carmo RMCV, Mourão LC, Tavares CMM, Tavares CMM. Reflections about the tutor in a university hospital: a case study. Online braz j nurs [Internet]. 2012 October [Cited 2014 Oct 2]; 11 (2): 47982. Available from: http://www.objnursing.uff. br/index.php/nursing/article/view/4016. Access: 2014 Oct 02. doi: http://dx.doi.org/10.5935/1676-4285.20125015 . 
6. Puppin MP, Sabóia VM. Interdisciplinarity: cornerstone of education on healthcare - a social research. Online brazj nurs [Internet]. 2012 October [Cited 2014 Oct 2]; 11 (2): 528-32. Available from: http://www.objnursing.uff.br/index.php/nursing/article/view/3983. Access: 2014 Oct 02. doi: http://dx.doi.org/10.5935/1676-4285.2012S026.

7. Mourão LC, L'Abbate S. Teaching implications in curricular transformations in the field of Health: a socio-historical analysis. Online braz j nurs [Internet]. 2011 December [Cited 2014 Oct 2]; 10 (3): . Available from: http://www.objnursing.uff. br/index.php/nursing/article/view/3423. Access: 2014 Oct 02. doi: http://dx.doi.org/10.5935/16764285.20113423.

8. Scherer MDA, Pires DEP, Jean R. A construção da interdisciplinaridade no trabalho da Equipe de Saúde da Família. Ciênc. saúde coletiva [Internet]. 2013 Nov [cited 2014 Oct 01]; 18( 11 ): 3203-3212. Available from: http://www.scielosp. org/scielo.php?script=sci_arttext\&pid=S1413$-81232013001900011 \&$ Ing $=$ en.

9. Alcantara LS, Sant'Anna JL, Souza MGN. Adoecimento e finitude: considerações sobre a abordagem interdisciplinar no Centro de Tratamento Intensivo oncológico. Ciênc. saúde coletiva [Internet]. 2013 Sep [cited 2014 Oct 02] 18( 9 ): 2507-2514. Available from: http://www.scielosp. org/scielo.php?script=sci_arttext\&pid=S1413$-81232013001700004 \&$ lng $=e n$.
All authors participated in the phases of this publication in one or more of the following steps, in According to the recommendations of the International Committee of Medical Journal Editors (ICMJE, 2013): (a) substantial involvement in the planning or preparation of the manuscript or in the collection, analysis or interpretation of data; (b) preparation of the manuscript or conducting critical revision of intellectual content; (c) approval of the versión submitted of this manuscript. All authors declare for the appropriate purposes that the responsibilities related to all aspects of the manuscript submitted to OBJN are yours. They ensure that issues related to the accuracy or integrity of any part of the article were properly investigated and resolved. Therefore, they exempt the OBJN of any participation whatsoever in any imbroglios concerning the content under consideration. All authors declare that they have no conflict of interest of financial or personal nature concerning this manuscript which may influence the writing and/or interpretation of the findings. This statement has been digitally signed by all authors as recommended by the ICMJE, whose model is available in http://www. objnursing.uff.br/normas/DUDE_eng_13-06-2013.pdf

Received: 09/29/2014

Revised: 09/29/2014

Approved: 09/29/2014 